\title{
TINGKAT KONEKTIVITAS FASILITAS WILAYAH PERTUMBUHAN/KAWASAN POTENSIAL KABUPATEN MOJOKERTO
}

\author{
Dian Dinanti ${ }^{1 *}$, Iman Tunas Pratama ${ }^{2}$ \\ Jurusan Perencanaan Wilayah dan Kota, Fakultas Teknik, Universitas Brawijaya ${ }^{1}$ \\ Jalan Mayjen Haryono 167 Malang 65141 \\ Badan Perencanaan Pembangunan Daerah Kabupaten Mojokerto ${ }^{2}$ \\ Jalan Ahmad Yani No. 16 Kabupaten Mojokerto \\ e-mail*: dinanti@ub.ac.id
}

\begin{abstract}
ABSTRAK
Penguatan konektivitas wilayah merupakan salah satu strategi yang ditempuh dalam rangka percepatan dan perluasan pembangunan ekonomi. Dalam mencapai keberhasilan pembangunan maka diperlukan tercapainya kondisi konektivitas yang ideal sehingga dapat mendukung perkembangan wilayah sehingga pemerataan pembangunan dapat tercapai. Tujuan penelitian ini adalah menilai tingkat konektivitas wilayah berdasarkan elemen-elemen baik sarana prasarana transportasi maupun interaksi penduduk dan ruang pada seluruh wilayah Kabupaten Mojokerto sehingga dapat diketahui permasalahan-permasalahan yang terkait dengan ketidakmerataan akses pada wilayah-wilayah di Kabupaten Mpjokerto. Teknik analisis yang digunakan adalah indeks konektivitas, indeks gravitasi dan indeks sentralitas marshall. Berdasarkan hasil perhitungan didapatkan nilai indeks konektivitas Kabupaten Mojokerto adalah >1, yaitu termasuk dalam klasifikasi wilayah yang maju dan memiliki konektivitas yang baik. Sebagian wilayah masih memerlukan pengembangan konektivitasnya adalah area sekitar pegunungan Arjuno-Welirang yang memiliki keterbatasan akibat topografi. Pada perhitungan indeks sentralitas marshall, Kecamatan Gedeg, Kemlagi, Mojosari dan Ngoro merupakan wilayah yang paling mudah untuk diakses yang berpotensial sebagai wilayah pemusatan kegiatan. Wilayah yang berpotensi ini juga memiliki indeks gravitasi yang tinggi, dimana kawasan yang memiliki daya tarik kuat yaitu di sekitar Kota Mojokerto dan pusat Kabupaten Mojokerto, yaitu wilayah yang juga telah dilalui oleh jalan arteri dan kolektor.
\end{abstract}

Kata Kunci : indeks konektivitas, perkembangan wilayah, infrastruktur jalan.

\begin{abstract}
Strengthening regional connectivity is one of the strategies in the context of accelerating and expanding economic development. One indication of the success of development is the fulfillment of ideal connectivity conditions that support regional development so that equitable development can be achieved. The purpose of this study is to assess the regional connectivity level based on the elements of transportation infrastructure, the population dan the spatial interaction in Mojokerto Regency so that problems related to access disparity in Mojokerto Regency can be identified. The analytical techniques used are connectivity index, gravity index and marshall centrality index. Based on the calculation results, the connectivity index value of Mojokerto Regency is >1, so it can be concluded that in general the growth of Mojokerto Regency is included in the classification of an advanced economy. The area around the Arjuno-Welirang mountains which have limitations due to topography is an area that is prioritized in the development of its accessibility. Based on the marshall centrality index calculation, Gedeg, Kemlagi, Mojosari, and Ngoro sub-districts are the easiest areas to access which have the potential as Regional Activity Centre. While on the gravity index, areas that have a strong attraction are around Mojokerto City and the center of Mojokerto Regency are traversed by arterial and collector roads
\end{abstract}

Keywords: connectivity index, regional development, transportation infrastructure.

\section{LATAR BELAKANG}

Pengembangan wilayah baik perkotaan maupun wilayah perdesaan memerlukan akses yaitu kemudahan atau keterjangkauan tersebut oleh wilayah lain atau keterjangkauan wilayah tersebut terhadap wilayah sekitarnya. Faktor akses dalam pendekatan sebelumnya disebut dengan factor eksternal yang berisi tentang daya interaksi, interrelasi, independensi wilayah dengan wilayahwilayah lain baik regional, nasional maupun global. Semakin tinggi nilai aksesibilitas wilayah tersebut terhadap wilayah lain maka semakin tinggi potensi perkembangan wilayah (Muta'ali, 2013).

Penguatan konektivitas wilayah merupakan salah satu strategi yang ditempuh dalam rangka percepatan dan perluasan pembangunan ekonomi (Muta'ali, 2015). Terdapat tiga prinsip konsep konektivitas antara lain: pertama, memaksimalkan pertumbuhan melalui kesatuan kawasan, bukan keseragaman (inclusive development) dengan menghubungkan pusat-pusat pertumbuhan. Kedua, memperluas pertumbuhan melalui konektivitas wilayah-wilayah melalui inter-moda 
supply chain system yang menghubungkan hinterland dan yang tertinggal dengan pusat-pusat pertumbuhan. Ketiga, mencapai pertumbuhan inklusif dengan menghubungkan daerah terpencil dengan infrastruktur dan pelayanan dasar dalam mendapatkan manfaat pembangunan.

Berdasarkan pengertian diatas, maka dalam agenda pembangunan saat ini, konektivitas dapat diartikan sebagai keberadaan aksesibilitas yang mampu mempermudah jangkauan antar wilayah yang berarti akses terhadap beranekaragam informasi yang tersedia dalam skala global yang mendukung pemerataan pembangunan ke seluruh wilayah. Adapun faktor-faktor yang mempengaruhi besar atau kecilnya suatu indeks konektivitas wilayah antara lain: (1) Tersedianya jaringan jalan antar daerah baik kondisi maupun jenis jalan yang mendukung dalam mengakses wilayah (Marbun, 1985:86) dengan penjelasan bahwa tingkat aksesibilitas itu tinggi atau rendah dapat dilihat dari banyaknya sistem jaringan yang tersedia pada daerah tersebut. Semakin banyak sistem jaringan yang tersedia pada daerah tersebut maka semakin mudah aksesbilitas yang didapat begitu pula sebaliknya semakin rendah tingkat aksesbilitas yang didapat maka semakin sulit daerah itu dijangkau dari daerah lainnya.

Tingkat konektivitas wilayah terkait dengan jaringan jalan secara definisi memiliki pengertian "perbandingan antara jumlah satuan permukiman dalam suatu wilayah dengan jumlah jaringan sistem transportasi (jalan) yang menghubungkan antar wilayah", (2) Keefektifan sistem jaringan yang dapat di akses oleh penduduk setempat (Mokogunto, 1997:54). Konektivitas juga dapat dilihat dari keterkaitan dan iteraksi antar wilayah yang dapat diukur dengan metode gravitasi dimana semakin besar angka interaksi yang dihasilkan oleh suatu wilayah maka semakin erat hubungan wilayah tersebut dengan daerah lainnya yang dilihat dari mobilitas penduduknya. Sistem pergerakan dan moda transportasi memiliki pengaruh langsung yang signifikan terhadap pola aktivitas kawasan. Semakin besar nilai gravitasi yang dihasilkan oleh kawasan pinggiran terhadap suatu zona di pusat kota maka semakin besar pula ketergantungan kawasan pinggiran tersebut terhadap zona/lokasi tujuan pergerakannya. (Muuzi, 2020)

Salah satu Program pembangunan Kabupaten Mojokerto seperti halnya wilayah lain di Indonesia pada khususnya selalu diprioritaskan pada pengembangan ekonomi wilayah. Untuk kabupaten Mojokerto, salah satu Tujuannya adalah pemerataan pertumbuhan ekonomi sesuai potensi daerah yang dimiliki Kabupaten Mojokerto dengan sasaran terciptanya infrastruktur perekonomian dalam peningkatan pemberdayaan lingkungan sosial ekonomi. Berdasarkan misi Kabupaten Mojokerto, demi menjalankan misinya pemerintah menyusun kebijakan terkait "menciptakan infrastruktur perekonomian dalam peningkatan pemberdayaan lingkungan sosial ekonomi" dengan indikator tersedianya sarana dan prasarana perhubungan. Kabupaten Mojokerto telah mengembangkan jaringan jalan dari mulai jaringan jalan yang berfungsi sebagai penghubung antar wilayahwilayah yang memiliki fungsi primer sampai dengan ke pelosok wilayah berupa penghubung permukiman. Kabupaten Mojokerto memiliki target untuk memastikan adanya pemerataan akses yang tertuang dalam Program Kepala Daerah dengan capaian kinerjanya sebesar 100\% sehingga pemerataan ekonomi dan pengembangan wilayah dapat tercapai

Sesuai dengan program pembangunan daerah di Kabupaten Mojokerto terkait dengan penguatan konektivitas, maka diperlukan adanya penilaian terhadap nilai indeks atau tingkat konektivitas wilayah Kabupaten Mojokerto saat ini. Dengan demikian akan dapat ditemukenali permasalahan yang masih dihadapi apabila indicator pembangunan belum tercapai.

\section{METODE}

\section{Lokasi Penelitian}

Lokasi penelitian yaitu di Kabupaten Mojokerto, Provinsi Jawa Timur. Kabupaten Mojokerto terdiri atas 18 Kecamatan, 299 Desa dan 5 Kelurahan. Berikut merupakan batas administrasi Kabupaten Mojokerto.

\begin{tabular}{|c|c|}
\hline Bagian Utara & $\begin{array}{l}\text { : Kabupaten Lamongan } \\
\text { dan Kabupaten Gresik }\end{array}$ \\
\hline Bagian Timur & $\begin{array}{l}\text { : Kabupaten Sidoarjo dan } \\
\text { Kabupaten Pasuruan }\end{array}$ \\
\hline Bagian Selatan & : Kota Batu \\
\hline & : Kabupaten Jombang \\
\hline Bagian Tengah & : Kota Mojokerto \\
\hline
\end{tabular}

\section{Metode Pengambilan Data}

Pengumpulan data dilakukan dengan mengkaji data sekunder yaitu Dokumen Kondisi Jaringan Jalan Kabupaten Mojokerto, Data Peta Citra dan Ekstisting Jaringan Jalan dan Data Pola Ruang Kabupaten Mojokerto berdasarkan RTRW Kabupaten Mojokerto Tahun 2012-2032. 


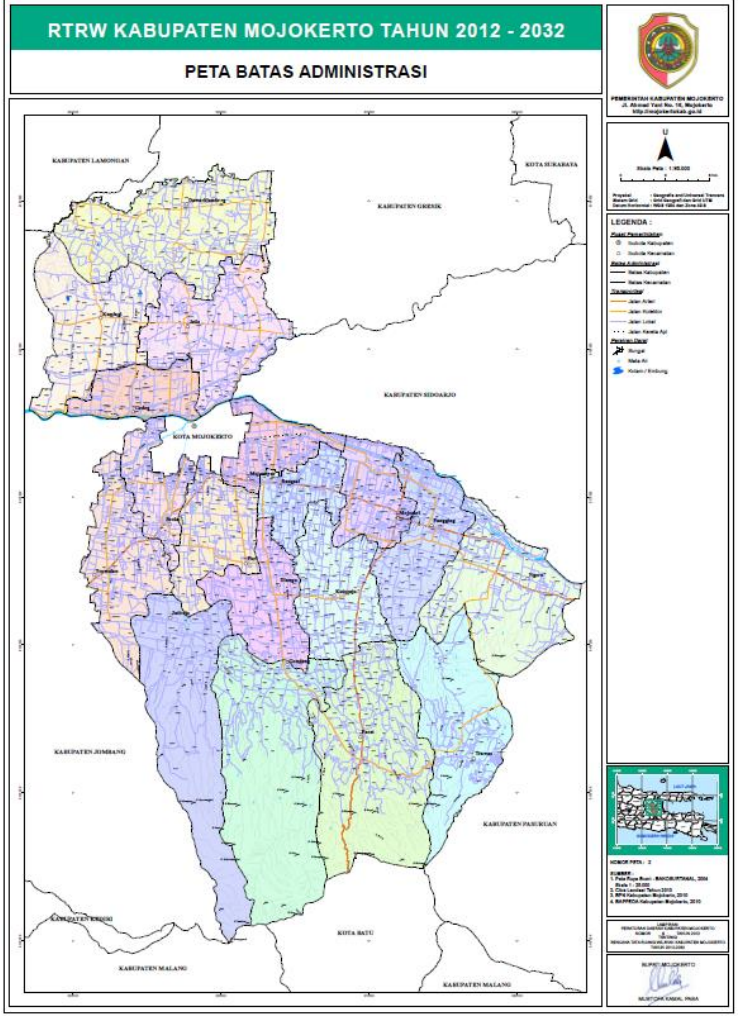

Gambar 1. Peta Batas Administrasi Kabupaten Mojokerto

\section{Teknik Analisis Data}

Tahap analisis data dilakukan dengan menggunakan rumus-rumus Konektivitas yang terdiri dari rumus perhitungan indeks konektivitas, rumus indeks gravitasi, rumus indeks sentralitas marshal serta korelasi antar variable topografi dengan nilai hasil indeks konektivitas

\section{Indeks konektivitas}

Indeks konektivitas adalah perbandingan antara jumlah satuan permukiman (kota) dalam suatu wilayah dengan jumlah jaringan sistem transportasi (jalan) yang menghubungkan kota tersebut dengan wilayah atau kota-kota lainnya.

Data yang dibutuhkan untuk mengukur indeks konektivitas adalah jumlah jalan penghubung antar kecamatan dan antar desa.

Perhitungan indeks konektivitas menggunakan rumus:

$\beta=e / V$

Keterangan:

$\mathrm{B}=$ Indeks konektivitas

$\mathrm{e}=$ Jumlah jaringan transportasi (jalan) yang menghubungkan satuan pemukiman (kota)

$\mathrm{V}=$ Jumlah satuan pemukiman di suatu wilayah
Hammond membuat batasan nilai beta dan menghubungkan dengan perkembangan wilayah sebagai berikut:

1. Jika $\beta>1$, menunjukan advanced ekonomies (wilayah maju).

2. Jika $\beta<1$, menunjukan backward ekonomies (wilayah terbelakang dan belum berkembang).

\section{Indeks gravitasi}

Indeks gravitasi digunakan untuk mengukur kekuatan keterkaitan antara pusat dan hinterland dan menentukan kekuatan tempat kedudukan dari setiap pusat kegiatan ekonomi terhadap wilayah lainnya. Rumus yang digunakan pada analisis gravitasi adalah sebagai berikut :

$I_{12}=G \frac{M_{1} \times M_{2}}{J^{b}{ }_{12}} V$

Keterangan :

$\mathrm{I}_{12}=$ Potensi daya tarik dan interaksi wilayah 12

$\mathrm{M}_{1}=$ Penduduk wilayah 1

$\mathbf{M}_{2}=$ Penduduk wilayah 2

$\mathrm{J}_{12}=$ Jarak antara wilayah 1 dan 2

$\mathrm{b}=$ Konstanta jarak

$\mathrm{G}=$ Konstanta proposional

Nilai $\mathrm{I}_{12}$ menunjukan potensi eratnya hubungan antar wilayah 1 dan 2 . Wilayah yang memiliki jumlah Nilai $I_{12}$ tertinggi biasanya memiliki ciri sebagai wilayah pusat, posisi strategis serta tingkat perkembangan wilayah yang tinggi.

Wilayah yang memiliki aksesibilitas tinggi dicirikan oleh potensi jumlah dan kepadatan penduduk tinggi, posisi geografis strategis dari wilayah lain dan fungsi wilayah yang lengkap.

\section{Indeks sentralitas marshall}

Indeks sentralitas merupakan sebuah analisis untuk mengetahui struktur/hierarki pusat pelayanan yang ada dalam suatu wilayah perencanaan, banyaknya jumlah fungsi pelayanan yang ada , banyaknya jenis fungsi pelayanan dan berapa jumlah penduduk yang dilayani serta seberapa besar frekuensi keberadaan suatu fungsi pelayanan yang ada (Muta'ali, 2015). Indeks sentralitas menunjukan nilai strategis wilayah berdasarkan aspek lokasi geografis, dimana wilayah tersebut dicirikan dengan kemudahan akses dan banyaknya link dan simpul transportasi yang mengumpul pada wilayah tersebut. Wilayah yang memiliki nilai sentralitas tinggi menunjukkan perkembangannya yang pesat, 
sebagai orientasi kegiatan dan menjadi wilayah tujuan (destination)

Indeks sentralitas marshall digunakan untuk mengetahui hierarki pusat-pusat pelayanan dalam suatu wilayah perencanaan pembangunan. Atribut yang dinilai dalam analisis ini adalah jumlah penduduk, kepadatan penduduk, tingkat aksesibilitas, ketersediaan fasilitas, skala pelayanan sarana, tingkat pelayanan jalan, dan urban compactness. Semakin tinggi ISMnya maka hierarki pelayanannya semakin tinggi. marshall.

Berikut merupakan rumus indeks sentralitas

$I S M=\frac{t}{T}$

Keterangan:

ISM = Indeks Sentralitas Marshall

$\mathrm{t}=$ Sentralitas gabungan (1000)

$\mathrm{T}=$ Jumlah atribut dalam perhitungan

Penilaian Indeks Konektivitas, Indeks sentralitas, Indeks gravitasi dan Indeks Aksesibilitas dilakukan terhadap 18 kecamatan yang ada di Kabupaten Mojokerto yang terdiri dari : Kecamatan Bangsal, Dawarblandong, Dlangu, Gedeg, Gondang, Jatirejo, Jetis, Kemlagi, Kutorejo, Mojoanyar, Mojosari, Ngoro, Pacet, Pungging, Puri, Sooko, Trawas, dan Trowulan

\section{HASIL DAN PEMBAHASAN}

\section{Gambaran Umum Kabupaten Mojokerto}

Kabupaten Mojokerto merupakan salah satu kabupaten di Provinsi Jawa Timur yang memiliki luas administrasi sebesar $969.360 \mathrm{~km}^{2}$. Jumlah penduduk Kabupaten Mojokerto Tahun 2018 adalah sebanyak 1.138.262 jiwa. Berikut merupakan potensi pengembangan Kabupaten Mojokerto (Tabel 1).

Tabel 1. Potensi Pengembangan

\begin{tabular}{|c|c|}
\hline Aspek & Potensi Pengembangan \\
\hline Industri & $\begin{array}{l}\text { Kemudahan askes transportasi eksport import, } \\
\text { berdekatan dengan akses tranportasi udara } \\
\text { (Bandara Udara Juanda) dan laut (Pelabuhan } \\
\text { Tanjung Perak) serta darat yaitu pembangunan } \\
\text { Tol Sumo. Terdapat penyediaan kawasan } \\
\text { peruntukan industri di Kecamatan Ngoro, Jetis, } \\
\text { Kemlagi, Dawarblandong, dan Mojoanyar. }\end{array}$ \\
\hline Infrastruktur & $\begin{array}{l}\text { Perlu adanya penunjang berupa pengembangan } \\
\text { infrastruktur jalan dan jembatan yang } \\
\text { menghubungkan dengan kawasan industri serta } \\
\text { daerah wisata guna meningkatkan pertumbuhan } \\
\text { ekonomi masyarakat pedesaan. }\end{array}$ \\
\hline Pendidikan & $\begin{array}{l}\text { Dalam pemenuhan tenaga kerja industri, upaya } \\
\text { yang dilakukan adalah penyediaan sarana } \\
\text { prasarana pendidikan yaitu Sekolah Menengah } \\
\text { Kejuruan (SMK) di beberapa lokasi kecamatan }\end{array}$ \\
\hline
\end{tabular}

\begin{tabular}{|c|c|}
\hline Aspek & Potensi Pengembangan \\
\hline & $\begin{array}{l}\text { sesuai dengan kebutuhan tenaga yang } \\
\text { dibutuhkan oleh industri. }\end{array}$ \\
\hline Kesehatan & $\begin{array}{l}\text { Dalam pembangunan manusia, Pemerintah } \\
\text { Kabupaten Mojokerto menitikberatkan pada } \\
\text { pengembangan bidang kesehatan antara lain } \\
\text { penyediaan Puskesmas dengan fasilitas rawat } \\
\text { inap. }\end{array}$ \\
\hline Pariwisata & $\begin{array}{l}\text { Terdapat obyek wisata Petirtaan Jolotundo } \\
\text { Trawas, Air Terjun Coban Canggu, Air Terjun } \\
\text { Dlundung Trawas, Wana Wisata dan Kolam Air } \\
\text { Panas Padusan Pacet, dan Ekowisata Waduk } \\
\text { Tanjungan Kemlagi yang rencananya akan } \\
\text { ditingkatkan sarana dan prasarananya. }\end{array}$ \\
\hline
\end{tabular}

\section{Kondisi Geografis dan Administratif Kabupaten Mojokerto}

Secara geografis wilayah Kabupaten Mojokerto terletak antara $111^{\circ} 20^{\prime} 13^{\prime \prime} \mathrm{s} / \mathrm{d}$ $111^{\circ} 40^{\prime} 47^{\prime \prime}$ BT dan antara $7^{\circ} 18^{\prime} 35^{\prime \prime}$ s/d 7 $47^{\circ}$ " LS. Rata-rata tingkat ketinggian Kabupaten Mojokerto berada kurang dari 500 meter di atas permukaan laut. Sekitar $30 \%$ dari keseluruhan wilayah memiliki tingkat kemiringan tanah lebih dari $15^{\circ}$, sedangkan sisanya merupakan dataran sedang dengan tingkat kemiringan kurang dari $15^{\circ}$. Tekstur tanah di Kabupaten Mojokerto antara lain tekstur halus $(26.405,4 \mathrm{Ha})$ dan tekstur sedang (70.530,6 Ha), serta memiliki 161 mata air dan 39 sungai natural.

Secara administrative Kabupaten Mojokerto memiliki 18 kecamatan, 299 desa dan 5 kelurahan. Kecamatan-kecamatan yang ada di Kabupaten Mojokerto antara lain : Kecamatan Bangsal, Dawarblandong, Dlangu , Gedeg, Gondang, Jatirejo, Jetis, Kemlagi, Kutorejo, Mojoanyar, Mojosari, Ngoro, Pacet, Pungging, Puri, Sooko, Trawas, dan Trowulan

\section{Jaringan jalan Kabupaten Mojokerto}

Kabupaten Mojokerto memiliki hieraki Jalan Arteri (1), Jalan Kolektor (9) dan Jalan Lokal (12.842), dengan status jaringan jalan yang terdiri dari Jalan Nasional, Jalan Propinsi, Jalan Kabupaten dan Jalan Lingkungan. Jumlah jaringan jalan yang berada di bawah kewenangan Kabupaten Mojokerto adalah sebanyak 342 ruas jalan.

\section{Analisis Pola Permukiman}

Bentuk permukiman pada Kabupaten Mojokerto terdiri dari dua yaitu permukiman perkotaan dan permukiman perdesaan yang memiliki 515 simpul permukiman. Berikut merupakan pola permukiman kawasan perkotaan di Kabupaten Mojokerto (Tabel 2). 
Tabel 2. Pola Permukiman Kawasan Perkotaan

\begin{tabular}{cl}
\hline $\begin{array}{c}\text { Kawasan } \\
\text { Pemukiman } \\
\text { Perkotaan }\end{array}$ & \multicolumn{1}{c}{ Lokasi } \\
\hline $\begin{array}{c}\text { Perkotaan } \\
\text { menengah }\end{array}$ & $\begin{array}{l}\text { Kecamatan Sooko, Gedeg, Mojosari dan Pacet } \\
\text { (Pusat Kegiatan Lokal dan PKL Promosi) }\end{array}$ \\
\hline $\begin{array}{c}\text { Perkotaan } \\
\text { kecil }\end{array}$ & $\begin{array}{l}\text { Kecamatan Ngoro, Mojoanyar, Jetis, Puri, } \\
\text { Trowulan, Kemlagi, Pungging (pusat pelayanan } \\
\text { kecamatan) }\end{array}$ \\
\hline $\begin{array}{c}\text { Kawasan } \\
\text { industri }\end{array}$ & $\begin{array}{l}\text { Sekitar Kecamatan Mojoanyar, Jetis dan Ngoro } \\
\text { (kegiatan sentra perindustrian) }\end{array}$ \\
\hline Kawasan \\
pariwisata & $\begin{array}{l}\text { Kecamatan Pacet dan Trawas (banyak kawasan } \\
\text { lindung) }\end{array}$ \\
\hline $\begin{array}{c}\text { Kawasan } \\
\text { strategis }\end{array}$ & $\begin{array}{l}\text { Kecamatan Jetis, Gedeg, Dawarblandong, Ngoro, } \\
\text { dan Trawas (pembangunan jalan tol Surabaya - } \\
\text { Mojokerto - Kertosono) }\end{array}$ \\
\hline
\end{tabular}

Pada kawasan permukiman desa mengikuti sumber produksi masyarakat setempat. Status kawasan permukiman desa adalah desa rural atau desa memiliki ciri pedesaan dan pertanian yang kuat. Umumnya perkembangan permukimannya linier mengikuti jaringan jalan.

\section{Indeks Konektivitas}

\section{Indeks Konektivitas Kabupaten Mojokerto}

Kabupaten Mojokerto pada tahun 2018 memiliki 342 ruas jaringan jalan yang berada di bawah kewenangan Kabupaten Mojokerto. Dari hasil perhitungan, dari 342 ruas jalan menghubungkan 304 wilayah (299 desa dan 5 kelurahan) sehingga dengan menggunakan Rumus indeks konektivitas diperoleh hasil Indeks Konektivitas Kabupaten Mojokerto adalah sebesar 1,125 . Nilai indeks tersebut menunjukkan bahwa $\beta>1$ yang berarti Kabupaten Mojokerto berada pada posisi advanced ekonomies (wilayah maju).

\section{Indeks konektivitas antar kecamatan}

Indeks konektivitas antar kecamatan menunjukkan tingkat keterhubungan antar Kecamatan di Kabupaten Mojokerto. Berdasarkan data, dari 342 ruas jalan yang ada, 18 kecamatan yang ada di Kabupaten Mojokerto hanya dihubungkan dengan 116 ruas jalan. Artinya untuk menghubungkan antar Kecamatan, hanya dihubungkan oleh 116 ruas jalan (Tabel 3).

Hasil perhitungan indeks konektivitas per kecamatan Kabupaten Mojokerto adalah sebesar 6,4 . Nilai indeks tersebut menunjukkan bahwa $\beta>1$ yang berarti berada pada posisi advanced ekonomies (wilayah maju). Hal itu menandakan bahwa semua Kecamatan di setiap kecamatan yang terdapat di Kabupaten Mojokerto tidak ada yang berstatus terisolir dan terbelakang. Semuanya sudah tergolong sebagai wilayah yang maju ditinjau dari keberadaan jalan sebagai fasilitas penghubungnya.

Tabel 3. Konektivitas Antar Kecamatan

\begin{tabular}{lll}
\hline \multicolumn{2}{c}{ Hubungan Antar Kecamatan } & Jalan Penghubung \\
\hline Dawarblandong & Kemlagi & 1 \\
\hline Dawarblandong & Jetis & 6 \\
\hline Kemlagi & Jetis & 3 \\
\hline Kemlagi & Gedeg & 5 \\
\hline Jetis & Gedeg & 2 \\
\hline Gedeg & Sooko & 2 \\
\hline Sooko & Trowulaan & 9 \\
\hline Sooko & Puri & 6 \\
\hline Trowulan & Jatirejo & 6 \\
\hline Puri & Jatirejo & 2 \\
\hline Puri & Dlangu & 6 \\
\hline Puri & Mojoanyar & 4 \\
\hline Jatirejo & Dlangu & 3 \\
\hline Jatirejo & Gondang & 6 \\
\hline Dlangu & Kutorejo & 3 \\
\hline Dlangu & Gondang & 2 \\
\hline Mojoanyar & Bangsal & 4 \\
\hline Mojoanyar & Mojosari & 2 \\
\hline Kutorejo & Mojosari & 3 \\
\hline Kutorejo & Pungging & 3 \\
\hline Kutorejo & Pacet & 4 \\
\hline Kutorejo & Gondang & 2 \\
\hline Gondang & Pacet & 4 \\
\hline Bangsal & Mojosari & 3 \\
\hline Bangsal & Kutorejo & 3 \\
\hline Pacet & Trawas & 3 \\
\hline Trawas & Pungging & 1 \\
\hline Trawas & Ngoro & 4 \\
\hline Mojosari & Pungging & Nalan \\
\hline Pungging & Ngoro & \\
\hline \multicolumn{1}{c}{ Total } & 18 kecamatan & \\
\hline & & 4 \\
\hline
\end{tabular}

\section{Indeks konektivitas antar desa}

Jumlah jalan penghubung yang menghubungkan 294 desa dan 5 kelurahan adalah sebanyak 688 jalan. Hasil perhitungan rata-rata indeks konektivitas antar desa dalam kecamatan adalah 2,29 (Tabel 4). Tidak ada indeks konektivitas < 1 yang menandakan bahwa desa dan kelurahan di setiap kecamatan yang terdapat di Kabupaten Mojokerto tidak ada yang berstatus terisolir dan terbelakang, serta sudah tergolong wilayah yang maju ditinjau dari keberadaan jalan sebagai fasilitas penghubungnya.

Tabel 4. Konektivitas Antar Pusat Desa

\begin{tabular}{cccc}
\hline Kecamatan & $\begin{array}{c}\text { Total Jalan } \\
\text { Penghubung }\end{array}$ & $\begin{array}{c}\text { Indeks } \\
\text { Konektivitas }\end{array}$ & $\begin{array}{c}\text { Klasifikasi } \\
\text { secara } \\
\text { intenal }\end{array}$ \\
\hline Bangsal & 40 & 2,67 & Tinggi \\
\hline Dawarblandong & 41 & 2,2 & Rendah \\
\hline Dlanggu & 35 & 2,19 & Rendah \\
\hline Gedeg & 32 & 2,29 & Sedang \\
\hline Gondang & 30 & 1,76 & Rendah \\
\hline Jatirejo & 40 & 2,22 & Sedang \\
\hline Kemlagi & 47 & 2,35 & Tinggi \\
\hline Kutorejo & 46 & 2,71 & Tinggi \\
\hline
\end{tabular}




\begin{tabular}{cccc}
\hline Kecamatan & $\begin{array}{c}\text { Total Jalan } \\
\text { Penghubung }\end{array}$ & $\begin{array}{c}\text { Indeks } \\
\text { Konektivitas }\end{array}$ & $\begin{array}{c}\text { Klasifikasi } \\
\text { secara } \\
\text { intenal }\end{array}$ \\
\hline Mojoanyar & 29 & 2,42 & Sedang \\
\hline Mojosari & 55 & 2,89 & Tinggi \\
\hline Ngoro & 40 & 2,11 & Rendah \\
\hline Pacet & 39 & 1,95 & Rendah \\
\hline Pungging & 49 & 2,72 & Tinggi \\
\hline Puri & 39 & 2,44 & Sedang \\
\hline Sooko & 37 & 2,47 & Sedang \\
\hline Trawas & 17 & 1,31 & Rendah \\
\hline Trowulan & 33 & 2,06 & Rendah \\
\hline Total & $\mathbf{6 8 8}$ & $\mathbf{2 , 2}$ & Sedang \\
\hline
\end{tabular}

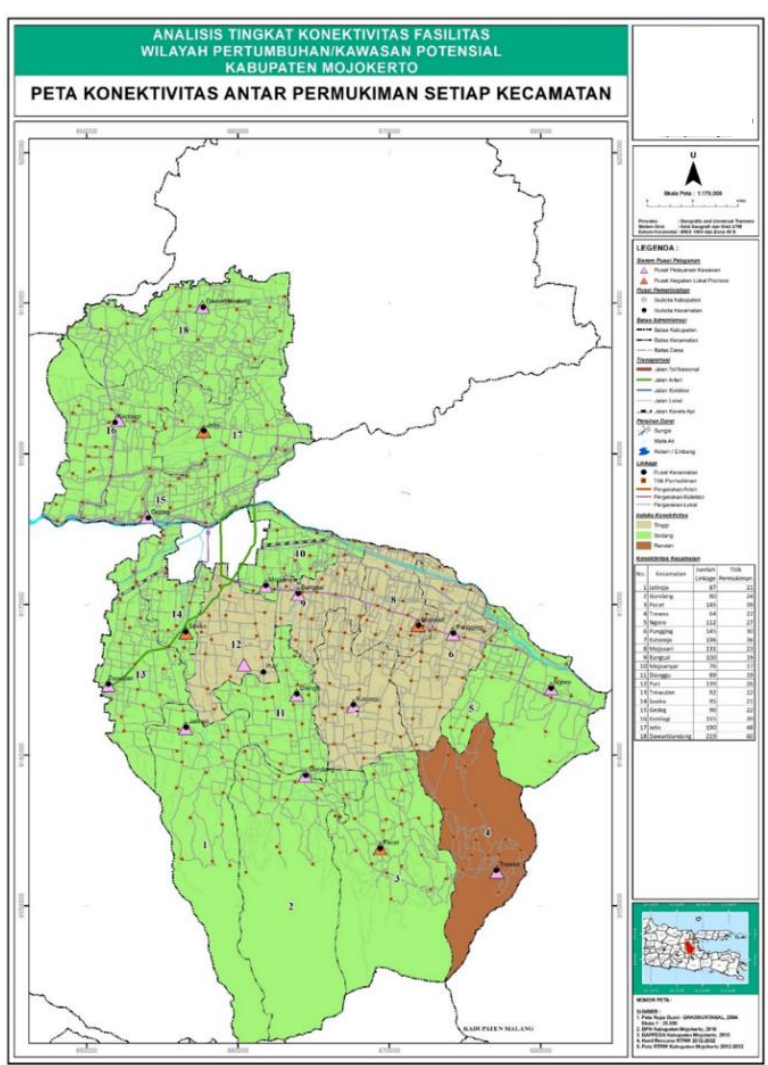

Gambar 2. Peta Indeks Konektivitas antar Desa

\section{Indeks konektivitas antar permukiman}

Kabupaten Mojokerto terdiri dari 299 desa dan 5 kelurahan yang memiliki 515 simpul permukiman dengan jumlah jalan penghubung sebanyak 2221 jalan. Berdasarkan jumlah jaringan jalan dan jumlah titik permukiman yang membutuhkan jaringan jalan tersebut, maka ditemukan nilai indeks 4,31. Nilai konektivitas permukiman dalam kecamatan masuk ke dalam kategori konektivitas baik dengan nilai rata-rata 4,31 (diatas 1). Konektivitas tinggi ada di 5 kecamatan (Punggng, Kutorejo, Bangsal, Mojosari dan Puri) sedangkan terendah adalah Kec. Trawas (Tabel 5). Kecamatan Trawas memiliki indeks konektivitas rendah karena secara posisi berada di kawasan pegunungan Arjuno Welirang yang terjal sehingga pengembangan jalan terbatas dan pertumbuhan permukiman yang relatif rendah dibanding kecamatan lainnya.
Tabel 5. Konektivitas Per Titik Permukiman

\begin{tabular}{lcccc}
\hline Kecamatan & Jalan & $\begin{array}{c}\text { Titik } \\
\text { Permukiman }\end{array}$ & Indeks & Klasifikasi \\
\hline Jatirejo & 87 & 21 & 4,14 & Sedang \\
\hline Gondang & 80 & 24 & 3,33 & Sedang \\
\hline Pacet & 145 & 39 & 3,72 & Sedang \\
\hline Trawas & 64 & 22 & 2,91 & Rendah \\
\hline Ngoro & 112 & 27 & 4,15 & Sedang \\
\hline Pungging & 145 & 30 & 4,83 & Tinggi \\
\hline Kutorejo & 196 & 36 & 5,44 & Tinggi \\
\hline Mojosari & 131 & 23 & 5,7 & Tinggi \\
\hline Bangsal & 100 & 19 & 5,26 & Tinggi \\
\hline Mojoanyar & 76 & 17 & 4,47 & Sedang \\
\hline Dlangu & 89 & 19 & 4,68 & Sedang \\
\hline Puri & 139 & 26 & 5,35 & Tinggi \\
\hline Trowulan & 92 & 22 & 4,18 & Sedang \\
\hline Sooko & 95 & 21 & 4,52 & Sedang \\
\hline Gedeg & 96 & 22 & 4,36 & Sedang \\
\hline Kemlagi & 165 & 39 & 4,23 & Sedang \\
\hline Jetis & 190 & 48 & 3,96 & Sedang \\
\hline Dawarblandong & 219 & 60 & 3,65 & Sedang \\
\hline Total & 2221 & 515 & 4,31 & Sedang \\
\hline
\end{tabular}

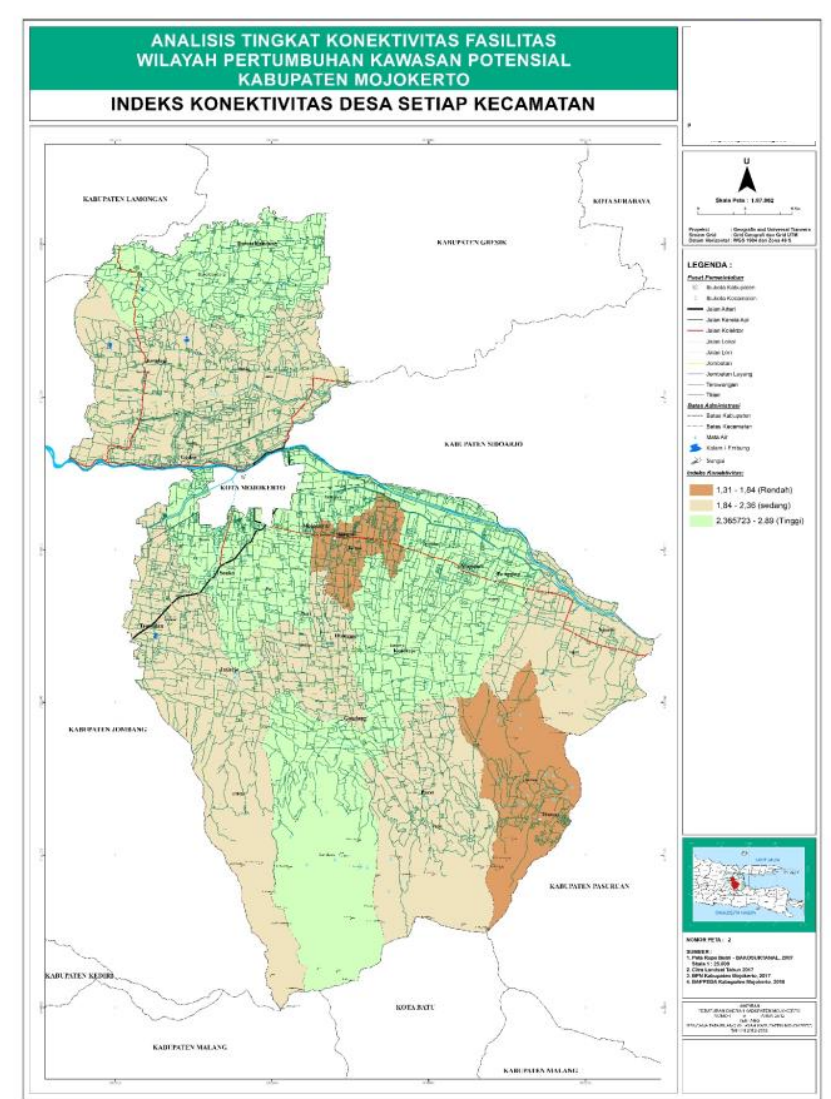

Gambar 3. Peta Indeks Konektivitas antar Permukiman

\section{Indeks konektivitas kawasan strategis dan potensial}

RTRW Kabupaten Mojokerto Tahun 20122032 merencanakan kawasan strategis dan potensial yang dibagi berdasar jenisnya, meliputi kawasan cagar budaya, kawasan agropolitan, kawasan cepat tumbuh, kawasan industri, 
kawasan pengembangan perkotaan baru, kawasan wisata alam dan kawasan rawan bencana.

Rata-rata kawasan strategis di Kabupaten Mojokerto memiliki nilai Indeks konektivitas >1 yang menunjukkan bahwa kawasan tersebut tergolong maju (Tabel 6).

Kawasan strategis Agropolitan, Kawasan Strategis cepat tumbuh dan kawasan strategis pengembangan perkotaan baru teridentifikasi memiliki indeks konektivitas >1 yang menunjukkan bahwa kawasan tersebut tergolong maju. Disisi lain kawasan strategis industri di utara sungai yang tergolong memiliki konektivitas yang rendah yaitu kawasan industri yang masuk dalam administrasi Kecamatan Dawarblandong dengan nilai indeks konektivitasnya $<1$. Industri lainnya yang teridentifikasi masih rendah konektivitasnya dengan wilayah lain adalah kawasan industri pada Kecamatan Bangsal, Dlangu, Mojosari dan Pungging. Rendahnya indeks konektivitas di kawasan industri bukan karena kawasan industri di Kabupaten Mojokerto tidak disediakan akses jalan, akan tetapi jalan bagi kawasan industri memang dikhususkan bagi lalu lintas kendaraan besar yang seminimal mungkin tidak mengganggu pergerakan ke area permukiman atau lokasi aktivitas lainnya.

Tabel 6. Indeks Konektivitas Kawasan Strategis dan Potensial di Kabupaten Mojokerto

\begin{tabular}{|c|c|c|c|c|c|}
\hline $\begin{array}{c}\text { Kawasan Strategis dan } \\
\text { Potensial Kabupaten }\end{array}$ & Sebaran & $\begin{array}{c}\text { Desa Kawasan } \\
\text { Strategis }\end{array}$ & $\begin{array}{c}\text { Jalan } \\
\text { Penghubung }\end{array}$ & $\begin{array}{c}\text { Indeks } \\
\text { Konektivitas }\end{array}$ & Klasifikasi \\
\hline Kawasan Cagar Budaya & Trowulan & 16 & 29 & 1,8 & Tinggi \\
\hline \multirow[t]{2}{*}{ Kawasan Agropolitan } & Gondang & 18 & 21 & 1,2 & Tinggi \\
\hline & Pacet & 2 & 3 & 1,5 & Tinggi \\
\hline \multirow{2}{*}{ Kawasan Cepat Tumbuh } & Gedeg & 14 & 14 & 1,0 & Tinggi \\
\hline & Sooko & 15 & 26 & 1,7 & Tinggi \\
\hline \multirow{3}{*}{$\begin{array}{c}\text { Kawasan Industri Utara } \\
\text { Sungai }\end{array}$} & Dawarblandong & 18 & 16 & $\mathbf{0 , 9}$ & Rendah \\
\hline & Jetis & 11 & 13 & 1,2 & Tinggi \\
\hline & Kemlagi & 15 & 15 & 1,0 & Tinggi \\
\hline \multirow{7}{*}{ Kawasan Industri Lainnya } & Bangsal & 5 & 3 & 0,6 & Rendah \\
\hline & Dlangu & 2 & 1 & 0,5 & Rendah \\
\hline & Ngoro & 13 & 14 & 1,1 & Tinggi \\
\hline & Pungging & 7 & 6 & $\mathbf{0 , 9}$ & Rendah \\
\hline & Puri & 3 & 6 & 2,0 & Tinggi \\
\hline & Sooko & 1 & 2 & 2,0 & Tinggi \\
\hline & Trowulan & 2 & 3 & 1,5 & Tinggi \\
\hline \multirow{3}{*}{$\begin{array}{c}\text { Kawasan Pengembangan } \\
\text { Perkotaan Baru }\end{array}$} & Dawarblandong & 4 & 5 & 1,3 & Tinggi \\
\hline & Jetis & 4 & 4 & 1,0 & Tinggi \\
\hline & Ngoro & 1 & 2 & 2,0 & Tinggi \\
\hline \multirow{3}{*}{ Kawasan Wisata Alam } & Pacet (wisata alam) & 20 & 27 & 1,4 & Tinggi \\
\hline & Trawas (wisata alam) & 13 & 22 & 1,7 & Tinggi \\
\hline & Kemlagi (waduk Tanjungan) & 1 & 2 & 2 & Tinggi \\
\hline \multirow{9}{*}{ Kawasan Rawan Bencana } & Kutorejo & 10 & 10 & 1,0 & Tinggi \\
\hline & Mojoanyar & 6 & 6 & 1,0 & Tinggi \\
\hline & Mojosari & 5 & 3 & 0,6 & Rendah \\
\hline & Ngoro & 12 & 9 & 0,8 & Rendah \\
\hline & Pacet & 12 & 9 & 0,8 & Rendah \\
\hline & Pungging & 4 & 1 & $\mathbf{0 , 3}$ & Rendah \\
\hline & \begin{tabular}{|l} 
Sooko \\
\end{tabular} & 4 & 1 & $\mathbf{0 , 3}$ & Rendah \\
\hline & Trawas & 10 & 11 & 1,1 & Tinggi \\
\hline & Trowulan & 2 & 1 & 0,5 & Rendah \\
\hline
\end{tabular}




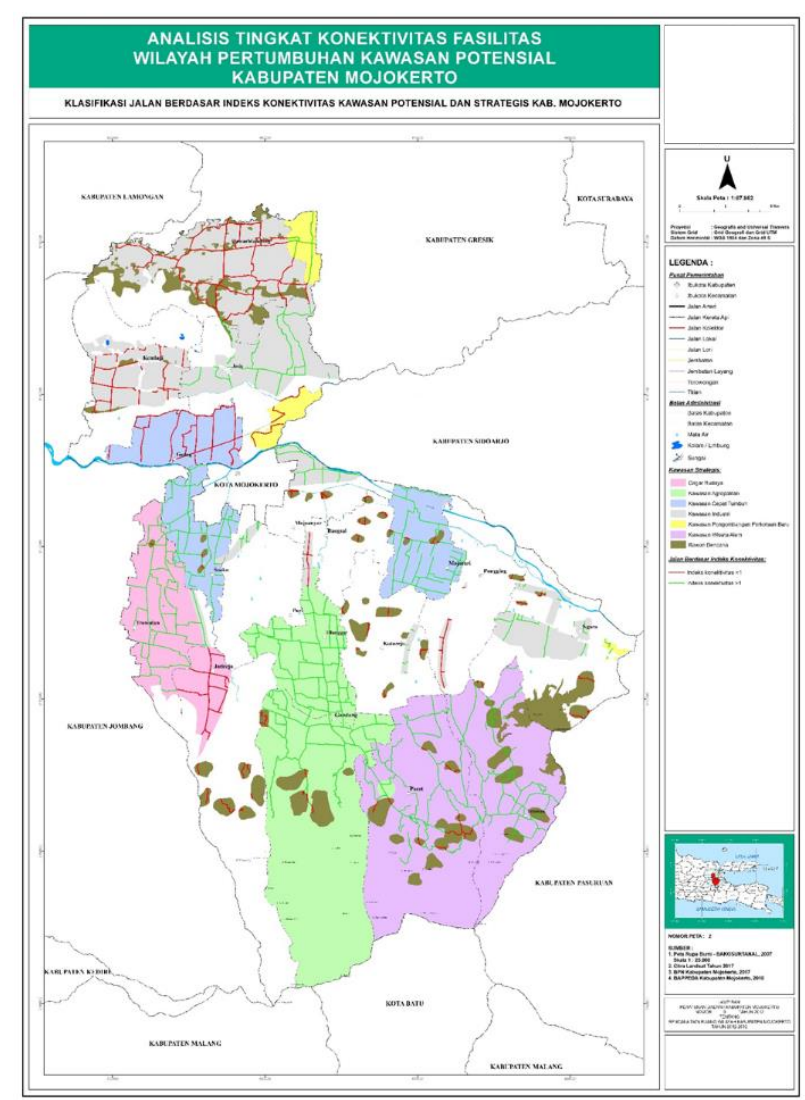

Gambar 4. Peta Indeks Konektivitas pada Kawasan strategis dan Potensial

\section{Indeks Gravitasi}

Analisis Gravitasi menunjukkan bahwa kawasan yang memiliki daya tarik kuat terkait dengan aktivitas di Kabupaten Mojokerto adalah kawasan yang dekat dengan kota dan pusat Kabupaten serta dilewati oleh jalan arteri dan kolektor. Sistem pergerakan dan moda transportasi memiliki pengaruh langsung yang signifikan terhadap pola aktivitas kawasan. (Muuzi, 2020). Keberadaan jalan tersebut memudahkan mobilitas penduduk kearah wilayahwilayah tersebut baik untuk mengakses fasilitas maupun untuk interaksi wilayah lainnya

Hasil pehitungan nilai gravitasi menunjukkan bahwa 5 kecamatan memiliki tingkat aksesibilitas yang tinggi dimana wilayah ini telah mampu memberikan pelayanan pada wilayah sekitarnya. Fungsi wilayah tertinggi ada pada Kecamatan Ngoro, Mojosari, Bangsal dan Sooko. Kelima wilayah ini dikatakan sebagai pusat kegiatan dimana mobilitas cenderung bergerak kearah ke 5 wilayah ini sehingga dapat dikatakan bahwa wilayah sekitarnya sangat tergantung kepada ke 5 wilayah ini. Pada kondisi eksisting dan juga berdasarkan analisis Indeks sentralitas marshall ke-lima wilayah ini juga memiliki peranan sebagai pusat pelayanan fasilitas, pusat pemasaran maupun permukiman sehingga juga memiliki fungsi sebagai lokasi tarikan maupun bangkitan pergerakan. (Tabel 10 dan Tabel 11).

Tabel 10. Nilai Gravitasi Antar Kecamatan

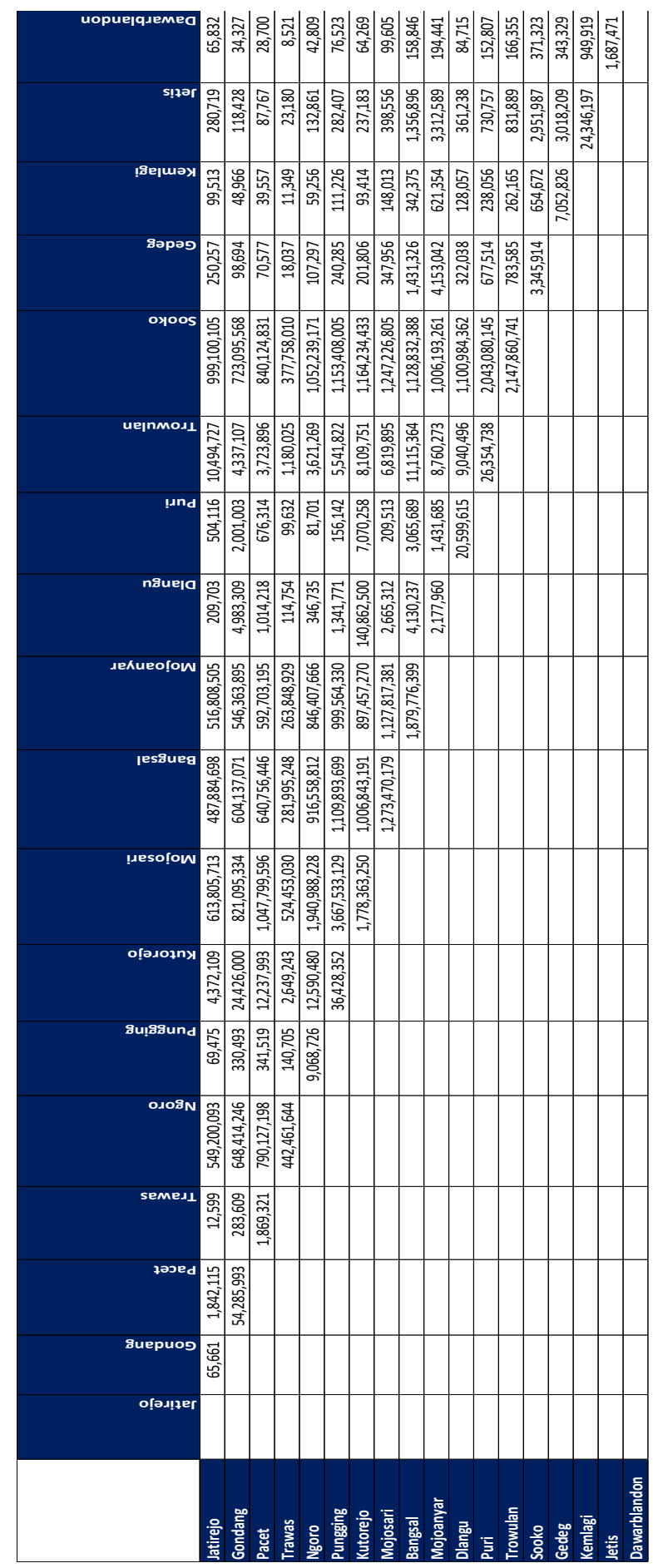

Indeks Sentralitas Marshall

Penentuan Indeks Sentralitas Marshall (ISM) diukur dari atribut jumlah penduduk, kepadatan penduduk, tingkat aksesibilitas, ketersediaan fasilitas, skala pelayanan sarana, tingkat pelayanan jalan, dan urban compactness. Pada bahasan penentuan ISM, indeks aksesibilitas 
dipergunakan untuk mengetahui seberapa besar interaksi antar wilayah dengan memperhatikan hierarki perkotaannya. Berikut merupakan hasil indeks sentralitas marshall terhadap 7 atribut tersebut dan perbandingan dengan arahan RTRW (Tabel 12).

Tabel 11. Indeks Konektivitas Berdasarkan Nilai Gravitasi

\begin{tabular}{cc}
\hline Kecamatan Tujuan & Klasifikasi \\
\hline Jatirejo & Rendah \\
\hline Gondang & Rendah \\
\hline Pacet & Sedang \\
\hline Trawas & Rendah \\
\hline Ngoro & Tinggi \\
\hline Pungging & Sedang \\
\hline Kutorejo & Sedang \\
\hline Mojosari & Tinggi \\
\hline Bangsal & Tinggi \\
\hline Mojoanyar & Tinggi \\
\hline Dlangu & Sedang \\
\hline Puri & Sedang \\
\hline Trowulan & Sedang \\
\hline Sooko & Tinggi \\
\hline Gedeg & Rendah \\
\hline Kemlagi & Rendah \\
\hline Jetis & Sedang \\
\hline Dawarblandong & Rendah \\
\hline
\end{tabular}

Tabel 12. Perbandingan Indeks Sentralitas Marshall

\begin{tabular}{|c|c|c|c|c|c|c|c|c|c|c|}
\hline \multirow[b]{2}{*}{ Kecamatan } & \multicolumn{8}{|c|}{ Indeks } & \multirow[b]{2}{*}{ ISM } & \multirow[b]{2}{*}{ Hierarki } \\
\hline & $\begin{array}{l}\text { Jumlah } \\
\text { Penduduk }\end{array}$ & $\begin{array}{c}\text { Kepadatan } \\
\text { Penduduk }\end{array}$ & $\begin{array}{c}\text { Keters } \\
\text { ediaan } \\
\text { Pelaya } \\
\text { nan } \\
\end{array}$ & $\begin{array}{l}\text { Aksesi } \\
\text { bilitas }\end{array}$ & $\begin{array}{c}\text { Skala } \\
\text { Pelayanan } \\
\text { Jalan }\end{array}$ & $\begin{array}{c}\text { Skala } \\
\text { Pelayanan } \\
\text { Sarana }\end{array}$ & $\begin{array}{c}\text { Urban } \\
\text { Compactness }\end{array}$ & Total & & \\
\hline Bangsal & 602,94 & 338,72812 & 47,64 & 9,31 & 795,45 & 172,84 & 879,505 & 2846,42 & 406,63 & II \\
\hline Dawarblandong & 609,64 & 336,70632 & 69,29 & 0,76 & 202,02 & 1000,00 & 517,17 & 2735,59 & 390,80 & II \\
\hline Dlangu & 657,48 & 586,57232 & 64,53 & 2,53 & 0,00 & 432,10 & 847,431 & 2590,65 & 370,09 & II \\
\hline Gedeg & 686,67 & 467,52849 & 47,21 & 1,06 & 909,09 & 654,32 & 797,248 & 3563,12 & 509,02 & I \\
\hline Gondang & 504,07 & 489,42283 & 49,37 & 0,55 & 0,00 & 37,04 & 944,252 & 2024,70 & 289,24 & III \\
\hline Jatirejo & 510,93 & 163,65275 & 58,47 & 0,71 & 0,00 & 61,73 & 874,222 & 1669,71 & 238,53 & III \\
\hline Jetis & 1000,00 & 389,33553 & 76,66 & 1,82 & 454,55 & 86,42 & 695,05 & 2703,82 & 386,26 & II \\
\hline Kemlagi & 692,37 & 710,6508 & 55,00 & 0,78 & 1000,00 & 283,95 & 1000 & 3742,76 & 534,68 & I \\
\hline Kutorejo & 761,61 & 173,20814 & 50,24 & 4,59 & 0,00 & 37,04 & 679,528 & 1706,21 & 243,74 & III \\
\hline Mojoanyar & 580,50 & 602,33406 & 39,41 & 4,29 & 454,55 & 283,95 & 783,066 & 2748,09 & 392,58 & II \\
\hline Mojosari & 922,28 & 277,40873 & 62,80 & $\begin{array}{c}1000,0 \\
0\end{array}$ & 956,94 & 246,91 & 632,758 & 4099,10 & 585,59 & I \\
\hline Ngoro & 959,85 & 1000 & 66,70 & 7,68 & 669,86 & 185,19 & 925,118 & 3814,38 & 544,91 & $\mathrm{I}$ \\
\hline Pacet & 685,45 & 293,24494 & 57,60 & 1,09 & 0,00 & 123,46 & 769,611 & 1930,46 & 275,78 & III \\
\hline Pungging & 906,83 & 623,2351 & 57,17 & 40,52 & 287,08 & 234,57 & 831,545 & 2980,95 & 425,85 & II \\
\hline Puri & 891,02 & 331,89945 & 44,17 & 2,10 & 340,91 & 37,04 & 788,88 & 2436,01 & 348,00 & II \\
\hline Sooko & 853,89 & 482,98635 & 48,51 & 2,79 & 727,27 & 123,46 & 915,759 & 3154,66 & 450,67 & II \\
\hline Trawas & 359,05 & 159,17486 & 48,07 & 0,48 & 0,00 & 37,04 & 733,378 & 1337,19 & 191,03 & III \\
\hline Trowulan & 876,21 & 228,96847 & 57,17 & 1,79 & 568,18 & 98,77 & 712,738 & 2543,82 & 363,40 & II \\
\hline
\end{tabular}

Berdasarkan hasil perhitungan ISM dapat ditarik kesimpulan bahwa kecamatan yang termasuk hierarki I adalah Kecamatan Gedeg, Kemlagi, Mojosari, dan Kecamatan Ngoro. Hierarki ini menunjukkan adanya potensial wilayah ini sebagai Pusat pelayanan Kabupaten. Apabila dibandingkan antara rencana RTRW dengan hasil perhitungan ISM ini maka terdapat beberapa wilayah yang berdasarkan evaluasi seharusnya memiliki fungsi wilayah yang lebih tinggi apabila dibandingkan dengan arahan dalam RTRW Kabupaten Mojokerto. Kecamatan yang memiliki potensi lebih tinggi dibandingkan arahan RTRW, yaitu Kecamatan Bangsal, 
Dawarblandong, Dlangu, Gedeg, Kemlagi, Mojoanyar, Pungging, Puri dan Trowulan. Sedangkan disisi lain ada satu Kecamatan yang berdasarkan perhitungan ISM seharusnya tidak memiliki hierarki yang tinggi yaitu Kecamatan
Pacet, dikarenakan Pacet jika dibandingkan dengan kecamatan lainnya, terindikasi kalah berkembang dibanding kecamatan lainnya.

Tabel 13. Perbandingan Indeks Sentralitas Marshall dan Arahan RTRW

\begin{tabular}{|c|c|c|c|c|c|}
\hline Kecamatan & Total Indeks 7 Atribut & ISM & Hierarki & Arahan RTRW & Hasil Identifikasi \\
\hline Bangsal & 2846,42 & 406,63 & II & PPK & Meningkat \\
\hline Dawarblandong & 2735,59 & 390,80 & II & PPK & Meningkat \\
\hline Dlangu & 2590,65 & 370,09 & II & PPK & Meningkat \\
\hline Gedeg & 3563,12 & 509,02 & $\mathrm{I}$ & PPK & Meningkat \\
\hline Gondang & 2024,70 & 289,24 & III & PPK & Tetap \\
\hline Jatirejo & 1669,71 & 238,53 & III & PPK & Tetap \\
\hline Jetis & 2703,82 & 386,26 & II & PKL Promosi Lokal & Tetap \\
\hline Kemlagi & 3742,76 & 534,68 & $\mathrm{I}$ & PPK & Meningkat \\
\hline Kutorejo & 1706,21 & 243,74 & III & PPK & Tetap \\
\hline Mojoanyar & 2748,09 & 392,58 & II & $\mathrm{PPK}$ & Meningkat \\
\hline Mojosari & 4099,10 & 585,59 & $\mathrm{I}$ & PKL Promosi Regional & Tetap \\
\hline Ngoro & 3814,38 & 544,91 & $\mathrm{I}$ & $\mathrm{PPK}$ & Tetap \\
\hline Pacet & 1930,46 & 275,78 & III & PKL Promosi Lokal & Turun \\
\hline Pungging & 2980,95 & 425,85 & II & PPK & Meningkat \\
\hline Puri & 2436,01 & 348,00 & II & PPK & Meningkat \\
\hline Sooko & 3154,66 & 450,67 & II & PKL Promosi Lokal & Tetap \\
\hline Trawas & 1337,19 & 191,03 & III & PPK & Tetap \\
\hline Trowulan & 2543,82 & 363,40 & II & PPK & Meningkat \\
\hline
\end{tabular}

\section{Korelasi Antara Topografi Kabupaten Mojokerto Dengan Konektvitas Antar Wilayahnya}

Korelasi antara kondisi topografi Kabupaten Mojokerto dengan indeks konektivitas dilakukan melalui tahapan overlay peta kelerangan dan peta indeks konektivitas yang dianalisis menggunakan SPSS.

Hasil korelasi kondisi kelerengan dengan indeks konektivitas antar desa (Tabel 14) menunjukkan bahwa terdapat hubungan yang signifikan antara indeks konektivitas dengan kondisi kelerengan Kabupaten Mojokerto karena baik melalui metode Kendall's tau b dengan Spearman's rho diketahui nilai signifikansi $<0,05$.

Korelasi antara kondisi kelerengan suatu wilayah di Kabupaten Mojokerto dengan konektivitas antar permukiman memiliki hubungan yang negative. Semakin besar kelerengan suatu wilayah maka konektivitas antar wilayahnya semakin rendah begitupun sebaliknya.

Hasil analisis korelasi dapat diperoleh kesimpulan bahwa di Kabupaten Mojokerto:

1. Indeks konektivitasnya sedikit banyak dipengaruhi oleh kondisi topografi atau kelerengan wilayahnya.

2. Semakin terjal/kelerengan suatu wilayah tinggi maka indeks konektivitasnya semakin rendah begitupun sebaliknya.
Tabel 14. Korelasi Antara Kelerengan dan Indeks Konektivitas Antar Desa

\begin{tabular}{|c|c|c|c|c|}
\hline \multicolumn{5}{|c|}{ Correlations } \\
\hline & & & $\begin{array}{c}\text { Indeks } \\
\text { Konektivitas } \\
\text { Antar Desa } \\
\end{array}$ & Kelerengan \\
\hline \multirow[t]{6}{*}{$\begin{array}{l}\text { Kendall's } \\
\text { tau_b }\end{array}$} & $\begin{array}{l}\text { Indeks } \\
\text { Konektivitas }\end{array}$ & $\begin{array}{l}\text { Correlation } \\
\text { Coefficient }\end{array}$ & 1.000 & $-.207^{*}$ \\
\hline & Antar Desa & Sig. (2-tailed) & & .024 \\
\hline & & $\mathrm{N}$ & 95 & 95 \\
\hline & Kelerengan & $\begin{array}{l}\text { Correlation } \\
\text { Coefficient }\end{array}$ & $-.207^{*}$ & 1.000 \\
\hline & & Sig. (2-tailed) & .024 & \\
\hline & & $\mathrm{N}$ & 95 & 95 \\
\hline \multirow[t]{6}{*}{$\begin{array}{l}\text { Spearman's } \\
\text { rho }\end{array}$} & $\begin{array}{l}\text { Indeks } \\
\text { Konektivitas }\end{array}$ & $\begin{array}{l}\text { Correlation } \\
\text { Coefficient }\end{array}$ & 1.000 & $-.233^{*}$ \\
\hline & Antar Desa & Sig. (2-tailed) & & .023 \\
\hline & & $\mathrm{N}$ & 95 & 95 \\
\hline & Kelerengan & $\begin{array}{l}\text { Correlation } \\
\text { Coefficient } \\
\end{array}$ & $-.233^{*}$ & 1.000 \\
\hline & & Sig. (2-tailed) & .023 & \\
\hline & & $\mathrm{N}$ & 95 & 95 \\
\hline
\end{tabular}

Konektivitas suatu daerah dipengaruhi oleh lokasi pembangunan jalan dan efisiensi jaringan jalan. Pembangunan jalan dibeberapa wilayah cenderung bersifat organik yang berarti perkembangan jalan berkembang dengan menyesuaikan kondisi topografi yang dan kebutuhan daerah. Keberadaan jaringan jalan di dapat memiliki variasi antara satu kecamatan dengan kecamatan yang lain, karena adanya perbedaan kebutuhan dan kondisi topografi. (Sreelekha et Al, 2016).

Pada umumnya desa-desa di Kabupaten Mojokerto khususnya pada Pegunungan Welirang 
memiliki topografi yang berlereng. Secara akses dan konektivitas, wilayah ini memiliki nilai konektivitas <1 khususnya pada Kecamatan Trawas. Kecamatan Pacet dan Trawas pada kondisi eksisting dan berdasarkan RTRW Kabupaten Mojokerto memiliki peranan sebagai kawasan strategis Pariwisata dengan perkembangan permukiman yang tumbuh cukup significant pada kedua kecamatan ini. Namun jumlah jaringan jalan penghubung dengan kacamatan maupun antar desa-desa pada kawasan ini sangat terbatas karena memiliki kondisi kelerengan yang cukup tinggi akibat berada di daerah pegunungan. Kondisi di area pegunungan pada Kabupaten Mojokerto memang memiliki kendala untuk pengembangan infrastruktur jalan karena topografi yang terjal hingga sangat terjal. Pembangunan jalan pada area berkelerengan tinggi memang membutuhkan teknik, biaya yang besar dan juga risiko yang besar sehingga jumlah akses jalan penghubung yang terbangun di wilayah ini menjadi sedikit

Aktivitas transportasi menunjukkan bahwa wilayah dilereng Gunung Welirang memiliki kecenderungan untuk membentuk pusat interaksi, namun kondisi tersebut mengalami kendala akibat nilai konektivitas yang kurang terbatas terutama pada Kecamatan Trawas, maka kemudian menyebabkan daya tarik ruang dari Kecamatan Trawas yaitu pariwisata tidak dapat terhubung dengan wilayah lain.

Diskonektivitas pada daya tarik ruang tersebut menunjukkan bahwa aktivitas transportasi tidak dapat berkembang dengan optimal dan belum mampu menjalankan fungsinya dengan baik dalam mendukung perkembangan wilayah yang ada yaitu sebagai pusat pariwisata dan permukiman. Aktivitas yang ada berkembang lebih dominan pada daerah tersebut, karena jaringan konektivitas di sekitarnya tidak mampu mendukung dengan optimal mobilitas unsur ruang yang ada (Wisnuaril, 2020) sehingga meskipun Trawas secara kegiatan berkembang namun menjadi kurang potensial sebagai pusat perkembangan

\section{KESIMPULAN}

Secara umum, pertumbuhan Kabupaten Mojokerto telah didukung oleh indeks konektivitas yang baik dengan nilai indeks $>1$, sehingga termasuk klasifikasi wilayah yang maju (advanced economy).

Ditinjau dari indeks konektivitas, antar pemukiman wilayah yang memiliki konektivitas rendah berada di area pegunungan (Kec. Trawas di pegunungan Arjuno-Welirang), sedangkan konektivitas tinggi berada di area yang dilalui jalan kolektor dan arteri (Kec. Pungging, Kutorejo, Mojosari, dan Bangsal). Sedangkan antar desa menunjukkan $>1$ artinya keseluruhan desa tidak berstatus terisolir dan terbelakang, serta tergolong wilayah yang maju ditinjau dari jalan (fasilitas penghubung) meskipun konektivitas pada beberapa desa khususnya pada daerah pegunungan memiliki indeks lebih rendah dibandingkan yang pada daerah relative datar.

Pada kawasan strategis kawasan yang memiliki konektivitas rendah $(<1)$, yaitu khususnya pada kawasan industry yang rata-rata hanya memiliki 1 jalan penghubung dan kawasan rawan bencana yang berada pada kawasan pegunungan.

Berdasarkan indeks gravitasi, kawasan yang memiliki daya tarik kuat yaitu berdekatan dengan Kota Mojokerto dan pusat Kabupaten Mojokerto, serta dilewati jalan arteri dan kolektor.

Indeks sentralitas Marshall menunjukkan bahwa Kecamatan Gedeg, Kemlagi, Mojosari dan Ngoro merupakan wilayah yang paling mudah untuk diakses (berpotensial sebagai wilayah pemusatan kegiatan), serta terdapat perubahan pusat pelayanan di Kabupaten Mojokerto. Ratarata wilayah yang dekat dengan wilayah perkotaan (Kec. Sooko, Gedeg) serta dekat dengan pusat Kabupaten Mojokerto (Kec. Mojosari) berpotensial sebagai pusat pelayanan. Dari keseluruhan konektivitas infrastruktur/ jalan, wilayah yang perlu diprioritaskan pengembangan konektivitasnya adalah area sekitar pegunungan Arjuno-Welirang yang memiliki keterbatasan akibat topografi

\section{PUSTAKA}

Kansky, K., J. (1963). Structure of Transportation Networks: Relationships, Between Network Geometry and Regional Characteristics. Chicago, University of Chicago

Keputusan Menteri Dalam Negeri Nomor: 050188/Kep/Bangda/2007 tentang Pedoman Penilaian Dokumen Perencanaan Pembangunan Daerah (Rencana Pembangunan Jangka Menengah Daerah/RPJMD)

Marbun, MA. (1985). Kamus Geografi. Jakarta: Ghalia Indonesia

Morlok, Edward K. (1988). Pengantar Teknik dan Perencanaan Transportasi. Jakarta, Erlangga.

Muumin Muuzi. (2020). Pola Mobilitas Penduduk Kawasan Pinggiran Kota Baubau (Studi Pada Kec. Betoambari Dan Kec. Wolio). Journal of Urban Planning Studies, Vol 1, No, 1, November 2020, pp 001-020. 
TINGKAT KONEKTIVITAS FASILITAS WILAYAH PERTUMBUHAN/KAWASAN POTENSIAL KABUPATEN MOJOKERTO

Muta'ali, Lutfi. (2015). Teknik Analisis Regional Untuk Perencanaan Wilayah Tata Ruang dan Lingkungan. Yogyakarta: Badan Penerbit Fakultas Geografi (BPFG)

Perda Kabupaten Mojokerto Nomor 9 Tahun 2012 Tentang RTRW Kabupaten Mojokerto Tahun 2012-2032

Perda Kabupaten Mojokerto Nomor 7 Tahun 2016 tentang RPJMD Kabupaten Mojokerto Tahun 2016-2021

Sreelekha, M.G; Krishnamurthy, K; danAnjaneyulu; M. V. L. R. (2016). Interaction between Road Network Connectivity and Spatial Pattern. Procedia Technology 24 (2016) $131-139$.

Undang-Undang No. 34 Tahun 2006 Tentang Jalan

Wisnuaril Khoirul Lukman. (2020). Interaksi Antara Jaringan Jalan Dengan Struktur Ruang Kabupaten Kendal, researchgate.net/publication/34860622. 